\title{
Students' Satisfaction as a Competitive Advantage in the Financial Products Market: A Comparative Study
}

\section{- Bañarová Michaela}

\begin{abstract}
The main task of today's banks, in both investigated countries, should be to prefer students' satisfaction and strive to offer them what they want. Nowadays, banks own many tools for satisfying their customers, however, there are still a number of areas where financial organizations could focus their attention to improve their relationships with students. The next related issue within the context of students in the banking environment is to gain an insight into student preferences on choosing a bank or purchasing bank products and services and find out which country provides more advantageous banking products and services and under what conditions, which type of marketing communication they prefer, and whether current bank marketing stimulates them to purchase. In this comparative study, a survey questionnaire was developed which incorporated the main findings of current literature on this issue. The results of self-administrated on-line questionnaires from Czech and UK higher education students will be presented in this article, involving one university from each country. The findings highlight that, while the conditions of provided student bank accounts are very similar and this type of bank account is very popular in both countries, the quantitative research found big differences in satisfaction with personal contact in banks and students' preferences. It was also confirmed that students in both countries resist special offers and marketing efforts of banks and in the area of their finances they rather trust in banking institutions with long-tested quality and reliability of services. The research also detected that satisfaction with price is significantly affected by paying bank charges among Czech students and further gaps in the range of banking products and the use of distribution channels are identified. A series of Fisher's tests, Pearson's tests, and Two-sample proportion tests were conducted to reveal these significant differences in student satisfaction and opportunities for gaining a greater competitive advantage.
\end{abstract}

Keywords: students, financial products/services, consumers' satisfaction, competitive advantage, bank marketing, bank distribution channels

JEL Classification: E21

\section{INTRODUCTION}

Students are going during their studies through transition from financial dependence to independence. According to Xiao, Shim, Barber and Lyons (2007, p. 2), students may have learned "consumer skills in cash management at home" before coming to high school and currently in college "they start to learn how to use credit, because they are just old enough to be able to sign credit cards contracts". Many of students are not cost-effective clients today but they can be very good and long term customers in the future. This is the reason why university students are be- 
coming more and more interesting as a group of clients for banking business and for many banks they represent an opportunity to grab potential high-earners as soon as possible. Banks are one of the most important intermediaries in a market economy, and competitive environment forces the banks to make different customer segments (Kuběnka \& Ptáčková, 2011). So, close relationships with customers are the main thing in the acquisition of more detailed information about consumers, and due to this it could be possible to achieve a competitive advantage in this environment. Dubey (2011) confirms this and she says that just this boost of customers' satisfaction with products and services is the key point in this competitive banking environment. Kuběnka and Ptáčková (2011) add that this competitive environment will demand much more creativity in terms of product and service development and according to them, the differentiation and innovation are the way how to hold the current customers or to gain the new ones.

\section{LITERATURE REVIEW}

\subsection{Consumer behavior of students}

Watson (2003) characterizes young people as people who grow in the consumption lifestyle and who lay emphasis on material ownership, prefer consumption rather than saving, and consider money to be vital for personal success. According to Goldberg, Gorn, Peracchio and Bamossy (2003), this heightened orientation towards materialism leads to young people's growing unhappiness. This is also shown in other research studies, which have suggested that youth perceive people living in affluence as individuals who make friends easily and are more intelligent, successful, and hardworking (Yurchisin, Johnson, 2004; Skafte, 1989; Dittmar \& Pepper, 1994). Chaplin and John (2007) confirm Watson's statement and they claim that young people, very much like adults, assess other people's regard for objects they own. So, this could be caused by the fact that more and more people prefer a single lifestyle as a result of the trend towards marrying later, and the priority of spending which is influenced by fashion and leisure. Ultimately, this leads to a wide range of credit behaviors and borrowing requirements (Fan, 2000). Today's society might want to regulate this through education, public policy, or otherwise. Goldberg et al. (2003, p.278) also confirm the statement of Watson and except that "more materialistic youth tend to shop more and save less," they add that youth are also "most interested in new products and most responsive to advertising and promotional efforts." Erskine, Kier, Leung and Sproule (2006) define the culture in which children now grow up as children's ready access to mass media which opens the "secrets" of adulthood to them and minimizes any differences in knowledge, perspective, and ultimately behavior between children and adults. The pressure of TV and social media, promotion, public relations, and packaging targeted at children and youth is still increasing. E-Marketer (2013) supplements this discussion by statistical data, and this company notes that over $\$ 66.35$ billion was spent on media advertising in 2011, up from $\$ 64.54$ billion in 2012 and set to rise to over $\$ 75$ billion by 2017. That is a compound annual growth rate of $3.7 \%$ between 2011 and 2017 in US. And Commins (2007) adds that global marketing today encourages consumers' product needs and materialistic values. So in recent years, consumers have been exposed to a wide variety of products and brands as a consequence of improved infrastructure and the opening of large shopping malls in most cities (Nieftagodien \& Van Der Berg, 2007). So, current consumers' purchases are done not only for their functional performance characteristics 
and utility, but most of them are value driven, and consumers try to display their status in life or social affiliation (Belk, 1984 in Christopher, Kuo, Abraham, Noel \& Linz, 2003; Pantzar, Raijas \& Eeiskanen, 2005). "The progression of this nature may boost excessive consumption and the use of credit to purchase goods that are difficult to afford" and such "behavior often results in credit abuse and financial mismanagement” (Delener \& Katzenstein, 1994 in Erasmus \& Mathunjwa, 2011, p. 361).

\subsection{Student Market for Financial Services}

"Over the past few years, financial institutions have been driven to become more customer-centric in an effort to retain current customers and attract new prospects as a response to a tougher regulatory environment and added competition from non-traditional sources" (Frank Aloi - ath Power CEO, PRNewswire, 2012). Kuběnka and Ptáčková (2011) add that since the banking system has changed from one to two-tier banking system, the marketing influence became more evident. The previous bank's approach to the client was strictly passive. With the introduction of two-level banking system, this industry has become increasingly competitive and demand driven with the appearance of new 'players' in the market and changing consumer behavior (Kuběnka \& Ptáčková, 2011). And the development of new products and technologies, and well-developed delivery systems, laying stress on market segmentation and target marketing, are supported due to competition in the banking sector (Desta, 2011; Kailash, 2012).

Dickler (2008) describes students as the heaviest users of financial services and student market products. Due to this, the banks are concentrating on young people as a key market for personal financial services with the aim of profit in the long term (Kuběnka \& Ptáčková, 2011). The situation of students at Universities is very advantageous for banks, because students are reliant on grants, loans, or financial support from their parents for financing their studies. There is also the expectation that students will have high incomes after their graduation and thus become a very attractive group of customers for banks. So, the banks strive to attract students with sales promotions and special offers, which differ from one to another, but the financial services and products, are not largely altered. Muellbauer (2008) adds that these special bank offers made in order to increase the width and depth of their product mix are for example NOW accounts, Club As, Christmas Club accounts, senior-citizen accounts, CDs, trusts, junior savings accounts, a number of new loan products, discount brokerage services, plus a host of commercial accounts. Yavas, Bilgin and Shemwell (1997) and Mishra et al. (2011) suggest that not only promotion can help private banks in gaining market share and stimulating demand for their services, and they also highlight branch expansion as another approach. Po-Young, Gin-Yuan and Yu (2012, p. 1271) moreover add that the battle for the customers is also in effort to improve performance and "information technology, in particular, is accelerating the banking industry revolution". And Jeyabalan (2013) claims that thanks to rational channel planning models retail banks can identify profitable customer segments attracted to branch banking, telephone banking, PC banking, and Internet banking, or combinations thereof. But according to Kuběnka, Ptáčková (2011) and Bingham, Lewis (1991) students' behavior in choosing a bank is influenced by convenience and their parents rather than free gifts and advertising. 


\subsection{Students' needs and satisfaction}

According to ČNB (2013) the competition in the banking market is still growing. In total, there are 45 banks in the Czech Republic to date of July 8th 2013. In the UK, there are 157 UK-incorporated banks, $48 \mathrm{UK}$ building societies, $652 \mathrm{UK}$ credit unions and 162 branches of overseas banks (Graduate Prospects, 2012). All firms will be subject to a baseline level of supervision aimed at reducing the probability of failure.This sector of services is among fastest growing sector in emerging economies and according to Schmidt (2010) this competitive environment forces the banks to adapt their products to their clients.

Belás (2013) claims that the clients' dissatisfaction is reflected in bank-switching and the lack of customer loyalty and Ernst \& Young's global consumer banking survey confirms that the number of consumers planning to change banks has risen from $7 \%$ to $12 \%$ year on year (U.S. Newswire, 2012). Bingham and Lewis (1991) and Belás (2013) add that the range of services and acceptance of clients' needs is important for prevention of this, and young people now require services on higher level than the young formerly expected, and there is a greater probability that students who switched banks in the past to do it again. Therefore, it is hard for the banks to predict if student will switch banks because of better service elsewhere. After comparing students with other segments of the market concerning young people, Belás (2008) found out that customer satisfaction is created in addition to objective parameters (as low cost overdraft facilities, free banking with low or no interest accounts,..) also by the system of subjective feelings (as more caring approach from bank employees, the queues, slow service, communication of services, approach to customer's needs,..) which can play a very important role in their level of satisfaction. According to Pilorge, current bank customers are taking control and "banks must re-evaluate customer trends region by region to prioritize products, enhance services, and ultimately give customers what they want" (Pilorge - Ernst \& Young's Financial Services Advisory Markets Leader for Europe, Middle East, India and Africa U.S. Newswire, 2012). House of Commons (2011) adds to this that the financial industry has become more competitive, and the ability of a financial institution to compete on price has nowadays become increasingly difficult, and Pilorge adds that pricing remains critical to customer satisfaction (U.S. Newswire, 2012). U.S. Newswire (2012) also says that this competitive environment is continuously intensifying, thanks to the trends of rapid technological change, increasing social media use and globalization of financial markets. The new order of competitors and today's maturing and competent bank customers with needs and expectations for high quality service force banks to pay attention to the quality of service and consumer satisfaction (Belás, 2010; Kailash, 2012). Po-Young et al. (2012, p. 1272) moreover claim that "the key to business survival and success is building and maintaining strong customer relationships" by satisfying customers with the whole range of products and services they offer and delivering high-quality service to customers. And Muntean and Stremtan (2011) add that consumer satisfaction is very important for the success of business because it was demonstrated that it is close related to repurchase, fidelity and profitability, especially in a banking environment. And this is so vital to organizations that it is relevant to investigate and measure the drivers of customer satisfaction and the results should be used as key elements to continuously improve the quality management system (Kaura, 2013; Muntean and Stremtan, 2011). 
Waqar and Bakhtiar (2012) define satisfaction as "the feeling of the consumer toward a product or service after it has been used." Churchill and Suprenant (1982, in Foscht, Maloles III, Swoboda \& Chia, 2010, p. 152) see this customer feeling as "a comparison of the rewards and costs associated with the use or purchase of a product or service in relation to the anticipated consequences of the use or purchase" and "they linked customer satisfaction to an attitude." Suman and Rohit (2012) claim that customer satisfaction with services consists of two elements, such as service encounter satisfaction and overall service satisfaction, and they suggest that repeated experiences with positively satisfying service create a more global feeling of satisfaction. Korauš (2011) differentiates two outputs of consumer satisfaction, namely repeated purchases and positive word of mouth, which will lead to a higher acceptance rate on the side of customer and higher degree of satisfaction and pride in their work on the side of employee. But in the event that the customer is unsatisfied, these two outcomes could cause negative 'word-of-mouth advertising,' which might have a serious damaging effect on the business (Yavas, Benkenstein $\&$ Stuhldreier, 2004). According to market research, a satisfied customer informs of his satisfaction on average 3 other people, while an unsatisfied customer shares his bad experience up to 11 people, which proves that a good reputation is built very slowly, while bad news about products or services spreads very fast. Korauš (2011) asserts that improvement of customer satisfaction also plays a role in banking strategy, because it is more expedient for banks to focus on existing customers and sustain them requires five times less of effort, time and money than to strive to acquire new ones.

\section{RESEARCH DESIGN AND METHODOLOGY}

The aim of the research was to explore student satisfaction with the range of student's banking products and services, which distribution channels and promotion activities banks usually use to attract students, and how students perceive and evaluate them. While taking the main objective of this survey into consideration, quota sampling was picked as the most suitable sampling technique for this research. Among the main advantages of this technique were the speed of implementing the sampling and the low costs.

This research adopted the quantitative research method, which focuses on numbers in order to alleviate the acquisition of representative sets of data, and the deductive approach, because this survey is concerned with the testing of present theories (Denscombe, 2003; Blaxter, 2006). As an approach to a time perspective for the investigation, a Cross-sectional study was chosen. This is the most widely used research design, in which all measures are taken at the same time, or in a short period of time (Robson, 2002). The researcher used self-administered on-line questionnaires, where responses were collected immediately after completion, and all respondents answered the same questions. This method was chosen due to the author's financial and time limits. The author tried to design questionnaires to be highly valid and understandable for students from both investigated countries, so a pilot study was accomplished before sending these questionnaires to responders. The main objective of this pilot study was to test whether all the questions in the questionnaires are comprehensible and are posed in a good way. This issue was compared in two countries, the Czech Republic and the United Kingdom and students in both investigated countries were very helpful, and approximately $50 \%$ of questionnaires were sent 
back filled in. The information and data were obtained through the structured questionnaire, which was distributed to 120 students in each country. Due to the limited number of respondents drawn from a specific geographical region, it can be assumed that results do not represent an accurate estimate of the examined trends in the banking sector of investigated countries and making the generalization of the findings is difficult. However, they can be an inspiration to improvement of banking products and services for students and can serve as a basis for further deeper research. This research was conducted in the year 2011. One university from each investigated country was chosen. In the Czech Republic, there were chosen Tomas Bata University in Zlin and the University of Huddersfield in the United Kingdom. These two universities were chosen because they are both smaller regionally focused universities and the researcher has a very good contact with this foreign university which was important to ensure the high response rate. All the questions in the questionnaires were based on literature reviews and these questionnaires were divided into 3 sections and consist of 38 questions. Different types of data were collected using this questionnaire. Generally there were nominal, ordinal, and interval data which were analyzed using Excel, SPSS and RGui386 software.

\section{RESULTS AND DISCUSSION}

All of this section is focused on overall satisfaction with bank services and products, benefits of students' bank accounts, and their primary preferences when choosing a bank or purchasing a banking product and service.

\subsection{Details about responders}

Nationality was one of the most important investigated factors. The main aim of the survey was to find differences between the two examined nationalities. Some respondents had to be excluded due to missing data. Consequently, the final count of Czech respondents was 45 students with student bank accounts and 40 respondents with student bank account came from Britain. The majority of all participating respondents were in the age range, from 18 to 26 years. Females made up $56.5 \%$ of the sample and males around $43.5 \%$. Around $92.5 \%$ of all involved English students and $95.5 \%$ of all Czech students had student bank accounts. The rest of them had other types of bank accounts, or did not have student bank accounts. Due to this, we can say that student bank accounts were very popular in both investigated countries. One student bank account was owned by $89.2 \%$ of all English students and in the Czech Republic, it was around $83.7 \%$ of respondents.

The most English students had their student bank accounts with HSBC, then with NatWest, and finally with Barclays. Česká spořitelna, then Komerční banka and ČSOB, were the favorite banks for opening student bank accounts in the Czech Republic. In the figure below, we can see an overview of banks where students had opened their accounts. 


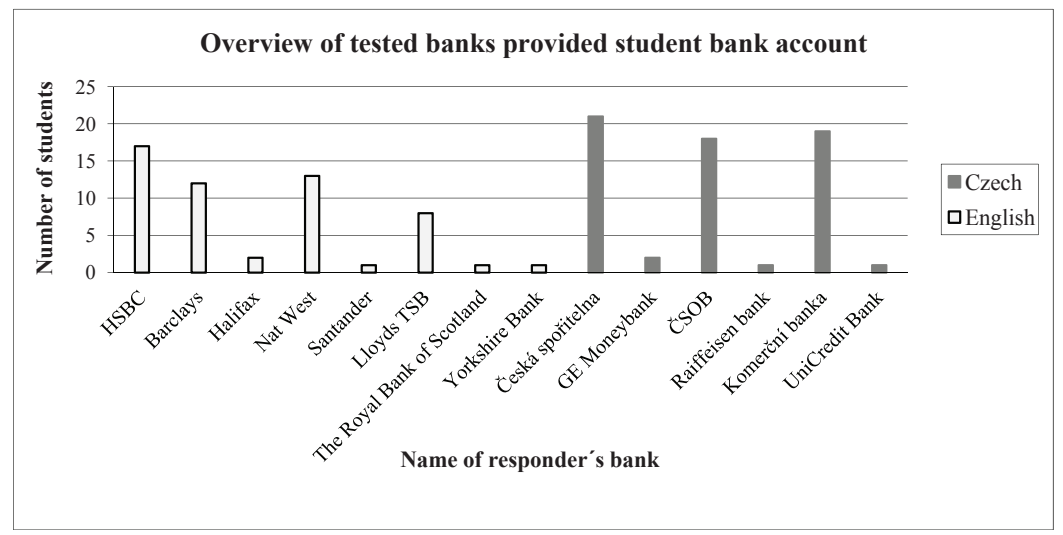

Fig. 1 - Overview of banks provided student bank account. Source: Author's own.

\subsection{Students' satisfaction}

The next figure illustrates the names of banks where students had opened their student bank accounts and the level of their satisfaction with products and services provided by their banks. The main researcher's aim was to find out which English and Czech banks offer the most satisfying products and services for students. In this figure, the high and very high level of satisfaction together is shown.

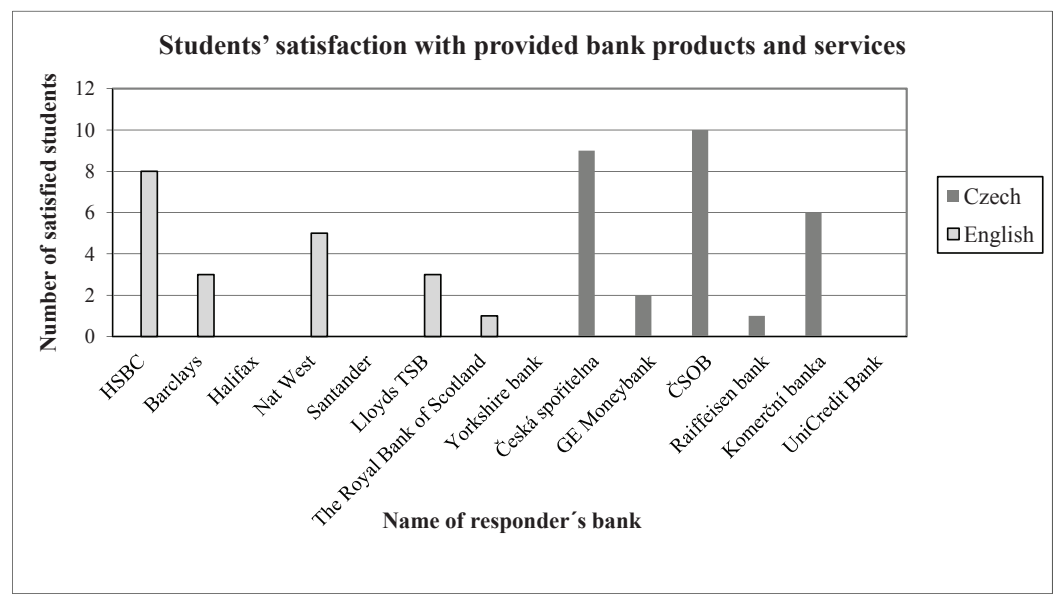

Fig. 2 - Students' satisfaction with banking products and services in the two investigated countries. Source: Author's own.

As can be seen there, English students were most satisfied with HSBC bank, and NatWest offered second most satisfying products and services in the UK. In the Czech Republic, students were most satisfied with services and products provided by ČSOB and Česká spořitelna. From the 
figure below, it is evident that English students evenly preferred the long-tested quality of provided services (35\%) and credibility and reputation of a bank $(35 \%)$ when they choose a provider of financial products and services. The credibility and reputation of a bank were in first place in the preferences of Czech students, as was the case with their English counterparts (44\%). But financial benefits played bigger role in Czech preferences and they were in second place (33\%), and the quality of provided services was in third place in the Czech Republic (18\%).

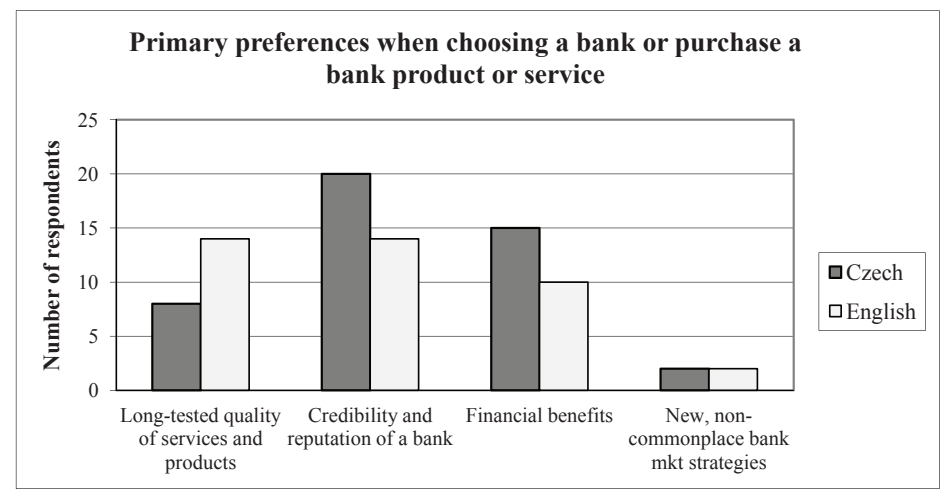

Fig. 3 - Students' primary preferences when choosing a bank or purchasing a banking product or service. Source: Author's own.

The next part is focused on banking products and services. In the following Pearson's chi-square test for independence, the researcher strived to ascertain if satisfaction with bank services and products differed by nationality. Satisfaction consisted of five levels: very high, high, medium, low, and very low.

H0: Satisfaction with bank services and products does not differ in the two investigated countries.

Tab. 1 - Satisfaction with banking products and services versus Nationality. Source: Author's own, SPSS.

\begin{tabular}{|l|c|c|c|}
\hline & \multicolumn{2}{|c|}{ Chi-Square Tests } & \\
\hline & Value & $\mathrm{df}$ & Asymp. Sig. (2-sided) \\
\hline Pearson Chi-Square & $4.619 \mathrm{a}$ & 2 & .099 \\
\hline Likelihood Ratio & 4.806 & 2 & .090 \\
\hline Linear-by-Linear Association & 2.721 & 1 & .099 \\
\hline N of Valid Cases & 120 & & \\
\hline a. 0 cells (,0\%) have expected count less than 5. The minimum expected count is 8,00. \\
\hline
\end{tabular}

The value of test criterion for Pearson Chi-Square is approximately 4.619 and Asymp. Sig. (2sided) for Pearson Chi-Square is 0.099. Since this is more than Sig. 0.05 we fail to reject the null hypothesis. So, we can claim that there is not a statistically significant relationship between sat- 
isfaction with bank services or products and nationality. English students in this research were satisfied at between the high and medium level alike as their Czech counterparts.

In the following part, the author used a Chi-Square and Two-Sample Proportion Test to find out if there is a significant relationship between the satisfaction of students and nationality. The results for all examined English and Czech students can be seen in the table below.

Tab. 2 - Satisfaction with bank services and products in the two investigated countries. Source: Author's own.

\begin{tabular}{|l|c|c|c|}
\hline bank product & cz & en & $\begin{array}{c}\text { p-value - proportion } \\
\text { test }\end{array}$ \\
\hline $\begin{array}{l}\text { Accessibility of banking products and services } \\
\text { from abroad }\end{array}$ & 0.26 & 0.35 & \\
\hline Debit card & 0.92 & 0.95 & \\
\hline Internet banking & 0.42 & 0.43 & \\
\hline Overdraft & 0.32 & 0.43 & \\
\hline Student loan & 0.13 & 0.43 & 0,0003914 \\
\hline
\end{tabular}

Tab. 3 - Two-sample proportion test. Source: Author's own, RGui386.

\begin{tabular}{|l|}
\hline R version 3.0.1 (2013-05-16) -- "Good Sport", Copyright (C) 2013 The R Foundation for Statistical \\
Computing, Platform: i386-w64-mingw32/i386 (32-bit) \\
\hline > prop.test $(\mathrm{x}=\mathrm{c}(8,26), \mathrm{n}=\mathrm{c}(62,60))$ \\
\hline 2-sample test for equality of proportions with continuity correction \\
\hline data: $\mathrm{c}(8,26)$ out of $\mathrm{c}(62,60)$ \\
X-squared $=\mathbf{1 2 . 5 7 2 9}, \mathbf{d f}=\mathbf{1 ,}$ p-value $=\mathbf{0 . 0 0 0 3 9 1 4}$ \\
alternative bypothesis: two.sided \\
95 percent confidence interval: \\
-0.4713132-0.1372889 \\
sample estimates: \\
prop $1 \quad$ prop 2 \\
$\mathbf{0 . 1 2 9 0 3 2 3 \quad 0 . 4 3 3 3 3 3 3}$ \\
\hline
\end{tabular}

According to chi-square tests for each tested bank product and service was found out that there is a statistically significant relationship only between the satisfaction with student loan and nationality. On the basis of this finding, the author tested if the proportions are equal in this case. The Two-Sample Proportion test reject the null hypothesis (chi $=12.57$, p-value $<0.001$ ) in favor of the alternative hypothesis which claims that the proportions are not equal. 
Tab. 4 - One-sample proportion test. Source: Author's own, RGui386.

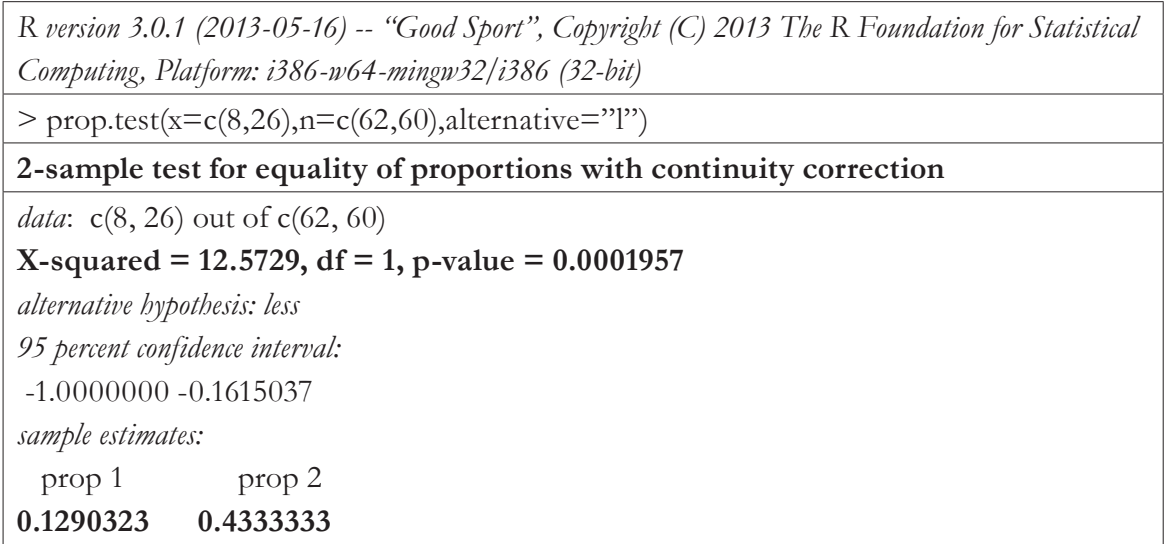

From one-sided proportion test point of view, the author reject the null hypothesis (chi $=12.57$, p-value $<0.001)$ in favor of the alternative hypothesis which says that proportion_1(8/62)< proportion_2(26/60). So, the proportion of students who were satisfied with student loan was different in the Czech Republic and the United Kingdom and English students were most satisfied with this type of bank product than their Czech counterparts 8 satisfied respondents from the Czech Republic and 26 from the United Kingdom). Otherwise, Czech students were satisfied at approximately the same level with debit cards, internet banking, overdraft, and accessibility of services from abroad as English students.

In the case of satisfaction with the range of banking products and services provided to students in both countries, students in the UK as in the Czech Republic were predominantly unsatisfied. They mentioned that they had regarded the range of these products and services as insufficient, and $65 \%$ of all respondents would appreciate a wider offer.

From price level of banking products point of view, the author used a Fisher's exact test due to the small sample and because both variables have exactly 2 categories. She decided to analyze independence of two qualitative variables, such as satisfaction with price of provided banking products and paying charges for the management and furnishing of statements for their student bank accounts. This dependence was investigated in both countries together.

H0: Satisfaction with price of provided banking products is not affected by paying charges for management and furnishing of statements for student bank accounts.

Tab. 5 - Satisfaction with price of provided banking products versus paying charges. Source: Author's own, SPSS.

\begin{tabular}{|l|c|c|c|c|c|}
\hline & \multicolumn{2}{|l|}{ Chi-Square Tests } & & & \\
\hline & Value & df & $\begin{array}{c}\text { Asymp. Sig. } \\
(2 \text {-sided })\end{array}$ & $\begin{array}{c}\text { Exact Sig. } \\
\text { (2-sided) }\end{array}$ & $\begin{array}{c}\text { Exact Sig. } \\
\text { (1-sided) }\end{array}$ \\
\hline Pearson Chi-Square & $10.866^{a}$ & 1 & 0.001 & & \\
\hline
\end{tabular}




\begin{tabular}{|c|c|c|c|c|c|}
\hline Continuity Correction ${ }^{\mathrm{b}}$ & 9.318 & 1 & 0.002 & & \\
\hline Likelihood Ratio & 12.207 & 1 & 0.000 & & \\
\hline Fisher's Exact Test & & & & 0.001 & 0.001 \\
\hline Linear-by-Linear Association & 10.735 & 1 & 0.001 & & \\
\hline $\mathrm{N}$ of Valid Cases & 83 & & & & \\
\hline \multicolumn{6}{|c|}{$\begin{array}{l}\text { a. } 0 \text { cells }(, 0 \%) \text { bave expected count less than } 5 . \text { The minimum expected count is } 9,76 \text {. } \\
\text { b. Computed only for a } 2 \times 2 \text { table. }\end{array}$} \\
\hline
\end{tabular}

Because expected frequencies were in this case less than 5 we use Fisher's Exact test. This way to look for differences is more precise than Pearson's Chi-Square. As can be gleaned from this table, the value of test criterion for the Fisher's Exact Test, Exact Sig. (2-sided) is 0.001. Since this is less than Sig. 0.05 we can reject the null hypothesis. So, results of Fisher's Exact Test showed that there is a statistically significant relationship between paying charges and students' satisfaction with prices.

H0: Satisfaction with the price of banking products is not affected by nationality.

Tab. 6 - Satisfaction with price of provided banking products versus nationality. Source: Author's own, SPSS.

\begin{tabular}{|l|l|l|l|l|l|l|}
\hline & Chi-Square Tests & & \\
\hline & Value & df & $\begin{array}{l}\text { Asymp. Sig. } \\
(2 \text {-sided })\end{array}$ & $\begin{array}{l}\text { Exact Sig. } \\
(2 \text {-sided })\end{array}$ & $\begin{array}{l}\text { Exact Sig. } \\
\text { (1-sided) }\end{array}$ \\
\hline Pearson Chi-Square & $32.058^{\mathrm{a}}$ & 1 & 0.000 & & \\
\hline Continuity Correction & & & \\
\hline Likelihood Ratio & 29.516 & 1 & 0.000 & & \\
\hline Fisher's Exact Test & 35.269 & 1 & 0.000 & & 0.000 & 0.000 \\
\hline Linear-by-Linear Association & 31.681 & 1 & 0.000 & & \\
\hline N of Valid Cases & 85 & & & & \\
\hline $\begin{array}{l}\text { a. } 0 \text { cells (,0\%) bave expected count less than 5. The minimum expected count is 13,65. } \\
\text { b. Computed only for a 2x2 table. }\end{array}$
\end{tabular}

Because expected frequencies were in this case less than 5 we use Fisher's Exact test again. As it is clear from this table, the value of test criterion for the Fisher's Exact Test, Exact Sig. (2-sided) is 0.000 . Since this is less than Sig. 0.05 we can reject the null hypothesis. So, results of Fisher's Exact Test showed that there is a statistically significant relationship between nationality and students' satisfaction with prices.

From the figure below this difference in the satisfaction with prices of banking products and services in both investigated countries is obvious. Majority of English students were very satisfied with the prices of banking products, while their Czech counterparts were only satisfied with reservations. This could be caused by the Czech banking policy due to which the majority of Czech banks require money for management and the furnishing of statements for student bank accounts, internet banking, saving accounts, overdrafts, payment orders or ATM withdrawals. 
Another reason may be high media coverage of cases around exorbitant bank charges on mortgages and generally hostile pricing policy of banks. Specifically, charges for transactions, making payments, saving accounts and interest in respect of overdrafts were mentioned most often as the main reservations of the Czech students. Most of these services are free of charge in the UK. According to English students, the only charges which could be more customer-friendly in the UK are the charges for exceeding authorized overdraft limits.

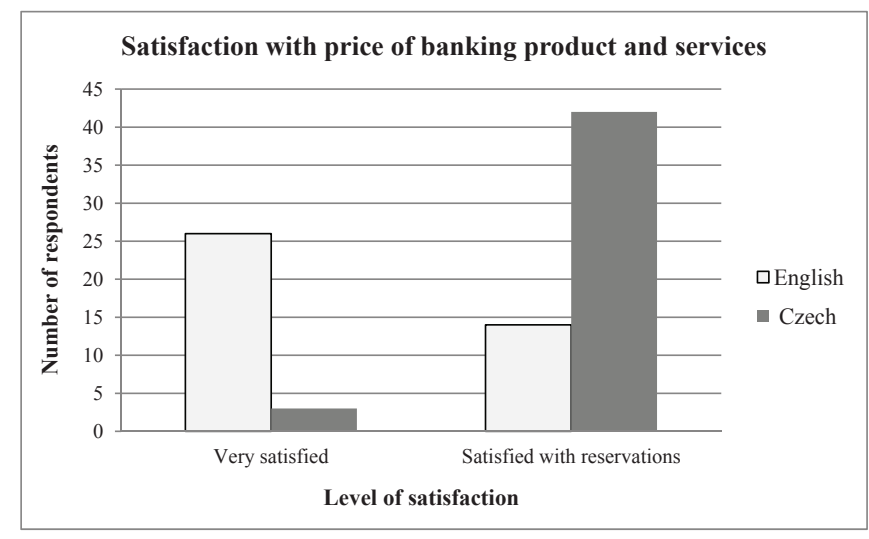

Fig. 4 - Students' satisfaction with price of banking products and services in the two investigated countries. Source: Author's own.

Further, the author examines whether satisfaction with the benefits of a student bank account depends on nationality, with the assistance of Pearson's chi-square test for independence.

H0: Satisfaction with the benefits of student bank accounts does not differ in the two investigated countries.

Tab. 7 - Satisfaction with the benefits of student bank accounts versus nationality. Source: Author's own, SPSS.

\begin{tabular}{|l|c|c|c|}
\hline & \multicolumn{2}{|c|}{ Chi-Square Tests } & \\
\hline & Value & df & Asymp. Sig. (2-sided) \\
\hline Pearson Chi-Square & $8.043^{\mathrm{a}}$ & 2 & .018 \\
\hline Likelihood Ratio & 8.261 & 2 & .016 \\
\hline Linear-by-Linear Association & 5.089 & 1 & .024 \\
\hline N of Valid Cases & 118 & & \\
\hline & a. 0 cells (,0\%) have expected count less than 5. The minimum expected count is 10,92.
\end{tabular}

Applying the analysis method led to obtaining the value of test criterion for Pearson Chi-Square 8.043 and Asymp. Sig. (2-sided) for Pearson Chi-Square is 0.018. Since this is less than Sig. 0.05, there is very strong evidence against the null hypothesis and we can reject it. We found out that 
there is a statistically significant relationship between student satisfaction with the benefits of student bank accounts and nationality at least of the 5\% significance level.

From bank marketing point of view we can say that English students were mostly captured by advertising $(63 \%)$ while their Czech counterparts mentioned a promotion as a marketing strategy which captured them the most (61\%). Sending letters is the most common method of distributing new bank offers in the United Kingdom (40\%). But it was interesting that $35 \%$ of all English respondents mentioned that they have never received a bank offer of new services and products. In the Czech Republic, banks mostly use e-mail as a distribution channel (31\%). But Czech banks also have gaps in their distribution strategy, because $24 \%$ of all Czech responders have never received a bank offer. In the figures below we can see students' evaluations of satisfaction with individual bank distribution channels.

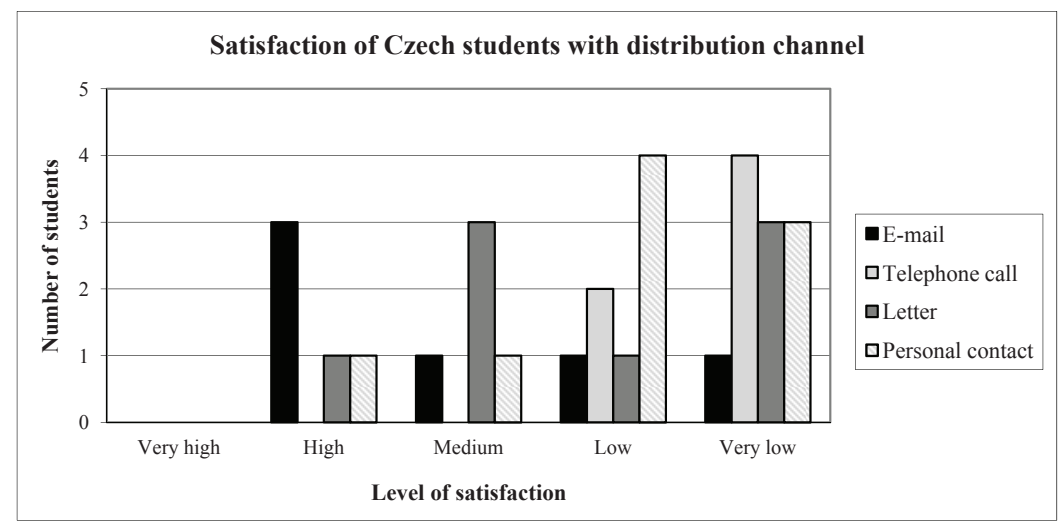

Fig. 5 - Satisfaction with the bank distribution channels among Czech students. Source: Author's own.

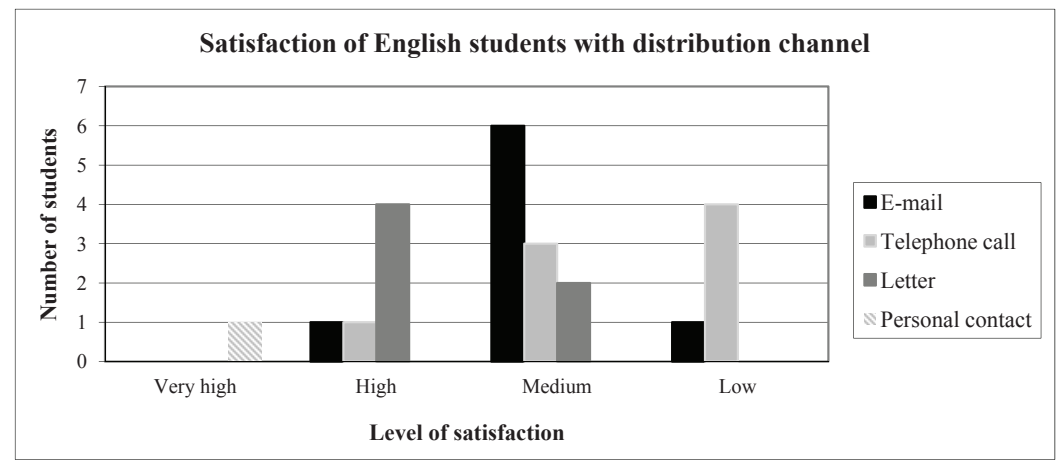

Fig. 6 - Satisfaction with the bank distribution channels among English students. Source: Author's own.

It is evident that English banks have very high-quality personal contact, which is not case of the Czech Republic, where students evaluated satisfaction with personal contact as low. Letters and Emails were selected as the most suitable and satisfactory channel for informing about new bank 
offer in both investigated countries. In the United Kingdom, students were unsatisfied with telephone calls and they were also selected as the least suitable distribution channel in the Czech Republic. Finally, the researcher examined which nationality is more suggestible when receiving a new bank offer, and on the basis of a Chi-square test it was found out that students in the two countries have not responded to new bank offers by purchasing, and they have not fallen prey to the press of bank marketing to any great degree.

\section{CONCLUSION}

Dickler (2008) defines students as the heaviest users of student market financial services and products, and they are a very prospective group of customers for today's banks. So, due to this, the banks are concentrating on young people as a key market for personal financial services, with the aim of profit in the long term (Kuběnka \& Ptáčková, 2011). On the basis of the results of this survey, it was found out that student bank accounts were very popular in both investigated countries and that most English students have opened their accounts with HSBC, NatWest, and then Barclays, while Czech students considered Česká spořitelna, Komerční banka, and ČSOB as their favorite bank for their needs. This finding confirmed the results of Kuběnka and Ptáčková's research from the year 2011, where the most favorite Czech banks for opening student bank accounts were ČS, KB and then ČSOB (Kuběnka \& Ptáčková, 2011). According to Jill Papworth, the most loved UK banks for students are Halifax, HSBC and Barclays (The Guardian, 2012). Bingham, Lewis (1991) and Belás (2013) say that young people now require service on a higher level than the young previously expected, and this is also evident from the results. Despite statement of Sandip (2013) that smaller and younger banks are usually more flexible and always helpful in satisfying customer requirements and demanding new banking products and providing better quality services, students in both investigated countries usually prefer to commit their money to financial institutions with long-tested quality and reliability of services. They do not enjoy experimentation and do not reflect so much on new, non-commonplace bank marketing strategies when they choose a financial institution. This was also proven during the testing of students' primary preferences on choosing a bank or purchasing a banking products or services. English students really prefer high quality of provided services, as well as the credibility and reputation of a bank. In the Czech Republic, on first place was the preference for the credibility and reputation of a bank as at their English counterparts. The importance of this finding is confirmed also by the statement of Corporate Executive Board (NYSE: EXBD - CEB, 2011) that "confidence increases product purchases and it is critical to the financial services industry" (China Weekly News, 2011, p. 14). But in second place, Czech students preferred financial benefits which confirmed the statement of Pilorge, that customers expect to be rewarded for the value of their business not just the duration of their banking relationships (U.S. Newswire, 2012).

Commins (2007) states in the literature review that consumers' product needs and materialistic values are today encouraged by global marketing, and Goldberg et al. (2003, p. 278) add that young people are today "most interested in new products and most responsive to advertising and promotional efforts." Yavas et al. (1997) and Mishra et al. (2011) respond to this by stating that not only promotion can help private banks in gaining market share and stimulating demand for 
their services, but also branch expansion can be very helpful in their efforts. When choosing a bank, English students in this survey were mostly captured by advertising, while their Czech counterparts mentioned a promotion as a marketing strategy which captured them the most. But Bingham, Lewis (1991) and Kuběnka, Ptáčková (2011) oppose by stating that students’ behavior when choosing a bank is influenced by their convenience and their parents' rather than free gifts and advertising. This was also proven in this survey where, on the basis of a Chi-square test, it was considered that students in the two countries did not respond to new bank offers by purchasing, and they have not fallen prey to the press of bank marketing to any great degree. This result also confirmed the findings of Kuběnka and Ptáčková, who claim that the recommendations of family and friends are on the top of each impulse with $83 \%$ for opening a bank account (Kuběnka \& Ptáčková, 2011) and Ernst \& Young's global consumer banking survey which found out that $71 \%$ of consumers relying on information from friends and family as their primary source (U.S. Newswire, 2012). Jeyabalan (2013) moreover add that the battle for the customers is, however, also fought through new electronic distribution channels available for financial service companies world-wide, and due to this it was also tested which channel was preferred among students in the investigated countries. Sending letters was the most common method of distributioning new bank offers in the United Kingdom. Czech banks mostly used e-mails as a distribution channel. The finding that English and also Czech banks do not use the right communication tools is confirmed by Kuběnka, Ptáčková's research, which shows that telephone and promotional email were never any stimulus for opening a bank account (Kuběnka \& Ptáčková, 2011). So, banks in both investigated countries had gaps in their distribution strategies, and on the basis of results were found out that $24 \%$ of all Czech respondents and 35\% of English respondents have never received bank offer of new services and products. From a students' satisfaction point of view, letters and emails were selected as the most suitable and satisfactory distribution channels in both countries.

Nowadays, the banks' offer is wide and it is easy to switch banks from day to day. Due to this, it is becoming more and more exacting for banks to keep their customers. And according to Muntean and Stremtan (2011), consumer satisfaction is one of the main and most important things in this competitive banking environment. Korauš (2011) adds that satisfied customer is willing to pay higher price for product or service and to divert satisfied customer to competitor means to reduce the price at the same value of the product or service up to $30 \%$. Suman and Rohit (2012) divide customer satisfaction of services into two elements, such as the transaction-specific satisfaction and overall satisfaction. On the basis of this survey it was proved that students were satisfied with overall banking products and services at between the high and medium levels in both countries. From an encounter satisfaction point of view, it was found out that there was a significant difference in satisfaction between the satisfaction with student loan and nationality of investigated students. English students were more satisfied with student loan than their Czech counterparts. With respect to other tested bank products and services was found out that the satisfaction rate is the same in both investigated countries. In the field of satisfaction with benefits of student bank accounts and special offers, no consideration was given to a significant difference between the levels of satisfaction in the investigated countries. This means that English students were satisfied with the benefits of student accounts and special offers at between the high and medium levels alike as their Czech counterparts. Bingham, Lewis (1991) and Belás 
(2013) mention the range of services and acceptance of clients' needs as an important factors for prevention of bank-switching and Kuběnka and Ptáčková (2011) verified in their research that complexity of bank services is important criterion for students. But this research examined the fact that students in both countries regarded the range of provided banking products and services as insufficient, and $65 \%$ of all respondents would appreciate a wider offer. This sad finding was also confirmed by big worldwide survey released by Ernst \& Young Global Ltd. (UK 1000 respondents, ČR 500 respondents) which found out that only $44 \%$ of customers consider their banking products and services as to meet their needs (U.S. Newswire, 2012). This should be a signal for banks that there is a need to focus on improving of student satisfaction in this area and prevent the further loss of clients. Korauš (2011) also draws attention to this statement, and says that improving customer satisfaction plays an important role in banking strategy because it is more expedient for banks to focus on existing customers and sustain them requires five times less of effort, time and money than to strive to acquire new ones. Belás (2008) claims, that the level of customer satisfaction is not affected only by low fees, interest rates and other objective parameters but that the subjective customer feelings may play a very important role in their level of satisfaction as well. Po-Young et al. (2012) add to this that delivering high-quality service to customers is necessity for success and survival in today's competitive banking environment. But in this survey it was found out that the quality of delivered services was different in the two countries. English banks had very high-quality personal contact, which was not case of the Czech Republic, where students evaluated satisfaction with personal contact as low. Ernst \& Young's global consumer banking survey (2012) confirmed the importance of this personal contact and claims that customers are looking to banks to help them and $26 \%$ of consumers stated the lack of personalized contact as reason for changing provider of financial services (U.S. Newswire, 2012). Also Belas's research found out low level of customer satisfaction with personal contact in Slovak banks (Belás, 2013). The high rate of satisfaction with personal contact among English students confirms that banks in the UK are aware that the customer is the priority for them, and a pleasant behavior and kindly approach are commonplace, while this area should be improved at Czech banks. From an overall satisfaction with quality of banking products and services point of view, the results proved that English students were most satisfied with HSBC bank and then with NatWest. In the Czech Republic, it was ČSOB then Česká spořitelna. As Novantas (2013) mentions, an increasingly competitive banking environment is leading bankers to adopt, more and more, a fee-based pricing strategy or based on comparison to competitors, with little attention to client factors and adds that pricing should be tailored to market segments, client behaviors and price sensitivity. Also the research of Kuběnka and Ptáčková proved that the amount of charges is important criterion associated with the keeping of account (Kuběnka, Ptáčková, 2011). The majority of Czech banks use two-part tariffs as a pricing strategy for student bank accounts. This means that students pay fixed annual or quarterly charges for services and then some extra charges, for instance for ATM withdrawals or money transactions. With respect to bank charges a significant difference between the investigated countries was examined. Czech students were not as satisfied with the prices of banking products as their English counterparts, and the author found out that paying charges can play a significant role in the satisfaction of Czech students. The charges for transactions, making payments, saving accounts and interest in respect of overdrafts were mentioned most often as the main reservations of the Czech students. 
This low rate of satisfaction could result in bank-switching, negative word-of-mouth advertising and high added costs for acquiring new clients as Belás (2013) just mentioned in the literature review. Belás (2013) also found out high customer dissatisfaction with price of banking products and services (59\%) among Slovak customers in his research and Ernst \& Young's global consumer banking survey (2012) confirmed that pricing remains critical to customer satisfaction and banks need to respond to this because $50 \%$ of their surveyed customers stated high fees as the main driver of bank-switching. So, Czech banks should consider another type of pricing strategy (U.S. Newswire, 2012). This recommendation was also confirmed by the research of Kuběnka, Ptáčková who found out that if the bank wants to obtain the students, it should follow the way of low fees (Kuběnka, Ptáčková, 2011).

Acknowledgement

Author is thankful to the Internal Grant Agency of FaME TBU No. IGA/64/FaME/11/D for financial support to carry out this research.

\section{References}

1. Half of Global Consumers Say Financial Institutions Don't Care About Them; 63 Million Financial Products Left Unsold Due to Lack of Confidence. (2011, May 14). China Weekly News, p.14. Retrieved from: http://search.proquest.com/docview/ 867392416 ?accountid $=15518$

2. Power in the banking relationship shifts dramatically to the consumer: - Percentage of customers planning to change their bank has almost doubled in the last year; - $70 \%$ of consumers would give banks more personal information if it improved service levels; - Only $44 \%$ of customers say their bank currently adapts products and services to meet their needs; - 91\% of consumers expect financial rewards for loyalty to their banks. (2012, July 30). U.S. Newswire. Retrieved from: http://search.proquest.com/docview/ 1030113671 ?accountid $=15518$

3. Overall Satisfaction Rates On The Rise Among Retail Banking Consumer - ath Power Study Reveals Customer Service Is Improving Though Other Issues Remain. (2012, December 18). PRNewswire. Retrieved from: http://www.athpower.com/home/ideal banking.php

4. Which? (2013). Best banks for customer satisfaction. Retrieved May, from: http://www.which. co.uk/money/bank-accounts/reviews-ns/bank-accounts/best-banks-for-customersatisfaction/

5. Belás, J. (2008). Retail banking. Bratislava: Iura Edition.

6. Belás, J. (2010). Management komeróných bánk, bankových obchodov a operácii. Žilina: Georg.

7. Belás, J. (2013). Satisfaction Mirror effect v Slovenskom Bankovom Sektore. Scientific papers of the University of Pardubice. Series D, Faculty of Economics and Administration, 25(3), 17-29.

8. Bingham, G. H., \& Lewis, B.R. (1991). The Youth Market for Financial Services. International Journal of Bank Marketing, 9(2), 3-11. http://dx.doi.org/10.1108/02652329110001 143

9. Blaxter, L., Hughes Ch., \& Tight M. (2006). How to research. Maidenhead: Open University Press. 
10. Commins, L. (2007). Credit Act: new rules for lenders, consumers. The Mercury Newspaper, $1-5$.

11. Česká Národní Banka. (2013). Celkový přbled počtu subjektů ke dni 6. 8. 2013. Retrieved August, 6, 2013, from: https://apl.cnb.cz/apljerrsdad/JERRS.WEB15.BASIC_LISTINGS_ RESPONSE_3?p_lang=cz\&p_DATUM=06.08.2013\&p_hie=HI\&p_rec_per_ page $=50 \&$ p_ses_idx $=1$

12. Denscombe, M. (2003). The good research guide: for small-scale social research projects. Maidenhead: Open University Press.

13. Desta, T., S. (2011). Perceived Quality of Services Rendered by Commercial Banks: A Case Study of State Bank of India (SBI), Panjab University (PU) Branch, Chandigarh, India. International Journal of Research in Commerce \& Management, 2(11), 26-35.

14. Dickler, J., (2008). Credit Card Debt on Campus: Unprepared Students Have Been Increasingly Targeted by Card Issuers, and Some Lawmakers Are Taking Notice. (2008, July 14). CNNMoney.com. Retrieved from: http://money.cnn.com/2008/07/10/pf/credit_ cards_college/index.htm?postversion=2008071416/

15. Dittmar, H., \& Pepper, L. (1994). To have is to be: Materialism and person perception in working-class and middle-class British adolescents. Journal of Economic Psychology, 15, 233 251. http://dx.doi.org/10.1016/0167-4870(94)90002-7

16. Dubey, S. (2011). Service Quality Perceptions: A Case Study of Banking Services. International Transactions in Applied Sciences, 3(3), 491-506.

17. E-Marketer. (2013). TV Advertising Keeps Growing as Mobile Boosts Digital Video Spend. Retrieved April, 3, from: http://www.emarketer.com/Articles/Print.aspx?R=1009780

18. Erasmus, A. C., \& Mathunjwa, G. Q. (2011). Idiosyncratic use of credit facilities by consumers in an emerging economy. International Journal of Consumer Studies, 35(3), 359-371. http://dx.doi.org/10.1111/j.1470-6431.2010.00946.x

19. Erskine, M., Kier, Ch., Leung, A., \& Sproule, R. (2006). Peer crowds, work experience, and financial saving behavior of young Canadians. Journal of Economic Psychology, 27(2), 262-284. http://dx.doi.org/10.1016/j.joep.2005.05.005

20. Fan, J. X. (2000). Linking consumer debt and consumer expenditures: do borrowers spend money differently? Family and Consumer Sciences Research Journal, 28(3), 357-400. http://dx.doi. org $/ 10.1177 / 1077727$ X00283004

21. Foscht, T., Maloles III, C., Swoboda, B., \& Chia, S. L. (2010). Debit and credit card usage and satisfaction. International Journal of Bank Marketing, 28(2), 150-165. http://dx.doi. org $/ 10.1108 / 02652321011018332$

22. Goldberg, M. E., Gorn, G. J., Peracchio, L. A., \& Bamossy, G. (2003). Understanding Materialism Among Youth. Journal of Consumer Psychology, 13(3), 278-288. http://dx.doi. org/10.1207/S15327663JCP1303_09

23. Graduate Prospects. (2012). Overview of the finance sector in the UK. Retrieved August, from: http://www.prospects.ac.uk/accountancy_banking_and_finance_sector_overview.htm 
24. House of Commons - Treasury Committee (2011). Competition and choice in retail banking (Ninth Report of Session 2010-11). London: Author. Retrieved from: www.parliament. $\mathrm{uk} /$ treascom

25. Chaplin, L. N., \& John, D. R. (2007). Growing up in a Material World: Age Differences in Materialism in Children and Adolescents. Journal of Consumer Research, 34(4), 480-493. http:// dx.doi.org/10.1086/518546

26. Christopher, A. N., Kuo, S. V., Abraham, K.M., Noel, L. W., \& Linz, H. E. (2003). Materialism and affective well-being: the role of social support. Personality and Individual Differences, 37(3), 463-470. http://dx.doi.org/10.1016/j.paid.2003.09.015

27. Jeyabalan, K. (2013). A Study on mobile banking in nationalised banks with reference to coimbatore city. Journal of Arts, Science \& Commerce, 4(1), 37-42.

28. Kailash, M. (2012). A Study on Customer Satisfaction with Service Quality in Indian Public and Private Sector Banks. Golden Research Thoughts, 1(9), 1-4.

29. Kaura, V. (2013). Antecedents of customer satisfaction: a study of Indian public and private sector banks. International Journal of Bank Marketing, 31(3), 167-186. http://dx.doi.org/10.1108 /02652321311315285

30. Korauš, A. (2011). Finančný marketing. Bratislava: Sprint.

31. Kuběnka, M., \& Ptáčková, P. (2011). Marketing of Banks - Segment of Students. Scientific papers of the University of Pardubice. Series D, Faculty of Economics and Administration, 20(2), 28-39.

32. Mishra, U. S., Mishra, B. B., Praharaj, S., \& Mahapatra, R. (2011). CRM in Banks: A Comparative Study of Public and Private Sectors in India. European Journal of Social Sciences, 24(2), 265-277.

33. Muellbauer, J. (2008). Housing, Credit and Consumer Expenditure. Centre of Economic Policy Research (CEPR).

34. Muntean, A., \& Stremtan, F. (2011). Research Regarding the Satisfaction of Bank Services Consumers at CEC Bank S.A. Annales Unversitatis Apulensis Series Oeconomica, 13(2), 655-661.

35. Nieftagodien, S., \& Van Der Berg, S. (2007). Consumption Patterns and the Black middle class: the role of assets. Bureau of Economic Research, 2, 1-10.

36. Novantas. (2013). Corporate banking. Retrieved from: http://www.novantas.com/corporate_ banking.php

37. Pantzar, M., Raijas, A., \& Eeiskanen, E. (2005). Green Consumers? Greening Consumption? Sustainable Consumption \& Production. Retrieved from: http://www.iisd. $\mathrm{ca} /$ consume/inst-pan.html

38. The best student bank accounts. (2012, August 10). The Guardian. Retrieved from: http:// www.theguardian.com/money/2012/aug/10/best-student-bank-accounts

39. Po-Young, Ch., Gin-Yuan, L., \& Yu, Ch. (2012). Service quality, customer satisfaction, customer trust, and loyalty in an e-banking context. Social Behavior and Personality, 40(8), 1271-1284. http://dx.doi.org/10.2224/sbp.2012.40.8.1271 
40. Robson, C. (2002). Real world research: a source for social scientists and practitioner-researchers. Madden Mass., Oxford: Blackwell Publishers.

41. Sandip, G. H. (2013). An Investigating Into Customer Satisfaction, Customer Commitment and Customer Trust: A Study in Indian Banking Sector. International Refereed Journal, 4(1), 96-102.

42. Skafte, D. (1989). The effect of perceived wealth and poverty on adolescents' character judgments. The Journal of Social Psychology, 129(1), 93-99. http://dx.doi.org/10.1080/00224545 .1989 .9711703

43. Suman, M., \& Rohit, G. (2012). Consumer Perception towards Quality of Financial Services (Urban vs. Rural Perspective). International Journal of Research in Finance \& Marketing, 2(2), 69-81.

44. Watson, J. J. (2003). The Relationship of Materialism to Spending Tendencies, Saving, and Debt. Journal of Economic Psychology, 24(6), 723-739. http://dx.doi.org/10.1016/ j.joep.2003.06.001

45. Waqar ul H., \& Bakhtiar, M. (2012). Customer Satisfaction: A Comparison of Public and Private Banks of Pakistan. Journal of Business and Management, 1(5), 1-53.

46. Xiao, J. J., Shim, S., Barber, B., \& Lyons, A. (2007). Academic Success and Well-being of College Students: Financial Behaviors Matter. University of Arizona, Tucson: TCAI.

47. Yavas, U., Bilgin, Z., \& Shemwell, D. J. (1997). Service quality in the banking sector in an emerging economy: a consumer survey. International Journal of Bank Marketing, 15(6), 217-223. http://dx.doi.org/10.1108/02652329710184442

48. Yavas, U., Benkenstein, M., \& Stuhldreier, U. (2004). Relationships between service quality and behavioral outcomes: A study of private bank customers in Germany. International Journal of Bank Marketing, 22(2), 144-157. http://dx.doi.org/10.1108/02652320410521737

49. Yurchisin, J., \& Johnson, K. K. P. (2004). Compulsive Buying Behavior and Its Relationship to Perceived Social Status Associated with Buying, Materialism, Self-Esteem, and Apparel-Product Involvement. Family and Consumer Sciences Research Journal, 32(3), 291314. http://dx.doi.org/10.1177/1077727X03261178

\section{Contact information}

Ing. Michaela Bañaŕová, BA(Hons)

Tomas Bata University in Zlin, Faculty of Management and Economics

Mostni 5139, 76001 Zlin, Czech Republic

Email:banarova@fame.utb.cz. 